\title{
Microbial formation of labile organic carbon in Antarctic glacial environments
}

\author{
Authors: Heidi J. Smith, Rachel A. Foster, Diane M. \\ McKnight, John T. Lisle, Sten Littmann, Marcel M. M. \\ Kuypers, \& Christine M. Foreman
}

This is a postprint of an article that originally appeared in Nature Geoscience on April 2017. https://doi.org/10.1038/ngeo2925.

Smith HJ, Foster RA, McKnight DM, Lisle JT, Littmann S, Kuypers MMM, et al. Microbial formation of labile organic carbon in Antarctic glacial environments. Nature Geoscience; 2017 April 3;10(5):356-9. DOI:10.1038/ngeo2925. 


\title{
Microbial formation of labile organic carbon in Antarctic glacial environments
}

\author{
H. J. Smith, R. A. Foster, D. M. McKnight, J. T. Lisle, S. Littmann, M. M. M. \\ Kuypers, and C. M. Foreman
}

Roughly six petagrams of organic carbon are stored within ice worldwide. This organic carbon is thought to be of old age and highly bioavailable. Along with storage of ancient and new atmospherically deposited organic carbon, microorganisms may contribute substantially to the glacial organic carbon pool. Models of glacial microbial carbon cycling vary from net respiration to net carbon fixation. Supraglacial streams have not been considered in models although they are amongst the largest ecosystems on most glaciers and are inhabited

by diverse microbial communities. Here we investigate the biogeochemical sequence of organic carbon production and uptake in an Antarctic supraglacial stream in the McMurdo Dry Valleys using nanometre-scale secondary ion mass spectrometry, fluorescence spectroscopy, stable isotope analysis and incubation experiments. We find that heterotrophic production relies on highly labile organic carbon freshly derived from photosynthetic bacteria rather than legacy organic carbon. Exudates from primary production were utilized by heterotrophs within $24 \mathrm{~h}$, and supported bacterial growth demands. The tight coupling of microbially released organic carbon and rapid uptake by heterotrophs suggests a dynamic local carbon cycle. Moreover, as temperatures increase there is the potential for positive feedback between glacial melt and microbial transformations of organic carbon.

Recent studies have focused on the fate and downstream implications of ancient organic carbon (OC) from coastal temperate and alpine glaciers1-3, with residual OC originatingfrom terrestrial or anthropogenic sources. Concomitant with this focus on allochthonous carbon, other studies have suggested that a large proportion of $\mathrm{OC}$ in supraand englacial settings may be composed of microbially generated products ${ }^{3-6}$, with in situ primary production being sufficient to accumulate $\mathrm{OC}^{7}$. Cryoconite ecosystems, in all glacial environments excluding Antarctica, may release $\sim 10$ $\mathrm{Gg} \mathrm{C} \mathrm{yr}{ }^{-1}$ of dissolved OC (DOC) ${ }^{8}$. The ecological importance of autochthonous OC production may be even greater for continental Antarctica, because of the absence of plants and the low aeolian inputs $5,9,10$. Therefore, we hypothesized that biological confributions are an important component of polar OC pools, particularly in supraglacial Antarctic environments, where inputs of biologically labile material can have amplified effects on downstream systems. The metabolic suitability of OC produced by microbial phototrophs in glacial environments is however largely unexplored, as highlighted in a recent review ${ }^{11}$.

Antarctic supraglacial systems

Aquatic ecosystems in the polar deserts of Antarctica have microbially dominated food webs with sparse invertebrates. Fur-ther, glacial meltwater streams are highly dilute, transient, and carbon cycling within the water column has not been studied. The goal of this study was to determine the composition and up-take rate of photosynthetically fixed $\mathrm{OC}$ within a large Antarctic supraglacial stream, to trace microbial OC transformations and advance our understanding of glacial carbon dynamics and global carbon cycles.
The supraglacial Cotton Glacier (CG) stream located in the McMurdo Dry Valleys of Antarctica is approximately $16 \mathrm{~km}$ long, eventually discharging into the Ross $\mathrm{Sea}^{12}$. Supraglacial streams are common features of coastal glaciers in Antarctica, with flow regimes influenced by solar radiation ${ }^{13}$. DOC concentrations throughout the summer in the CG stream ranged from 0.44 to 1.68 mg C $1^{-1}$ (ref. 12), similar to reported DOC concentrations of other glacial meltwaters $\left(\sim 0.12-0.72 \mathrm{mg} \mathrm{C}^{-1}\right)^{1,14}$. The OC fluorescence signa-ture of freshly collected stream water was dominated by protein-like fluorophores (designations B and T; 93\%, Table 1 and Supplemen-tary Fig. 1), which are associated with biogeochemically labile $\mathrm{OC}$, most likely produced by filamentous cyanobacteria and diatoms (Supplementary Table 1). Similarly, $97 \%$ of the fluorescent fraction of freshly synthesized microbial exudates from incubation exper-iments consisted of protein-like signatures, with greater tyrosine-like fluorescence compared with the CG stream water (Table 1 and Supplementary Fig. 1). After bacterial processing, exudates were comprised of $53 \%$ and $47 \%$ protein- and humic-like fluorescence signatures, respectively (Table 1 and Supplementary Fig. 1), indica-tive of the biological formation of more refractory materials ${ }^{15}$. The $\delta^{13} \mathrm{C}-\mathrm{DOC}$ values for the CG stream water were enriched and ranged from -19.0 to $-19.9 \%$ when compared with the DOC derived from surrounding glacial ice $(-29.5$ to $-30.1 \%)$ ( $P<0.001$, two tailed, $t$-test). As glacial ice serves as the stream water source, such differences in $\delta^{13} \mathrm{C}$ values are characteristic of in situ production and transformation ${ }^{16}$.

Microbial production of glacial organic carbon

The amount of extracellularly released OC in the CG stream at the height of the summer was found to be $50.7 \%$, as determined 
Table 1 | Summary of fluorescence data.

\begin{tabular}{llll} 
Fluorophore designation & $\begin{array}{l}\text { CG stream } \\
\text { water }\end{array}$ & $\begin{array}{l}{ }^{13} \text { C-labelled } \\
\text { exudates }\end{array}$ & $\begin{array}{l}\text { Exudate } \\
\text { feedback }\end{array}$ \\
\hline Protein-like 'B' & 76.10 & 48.59 & 35.45 \\
Protein-like 'T' & 17.45 & 49.36 & 17.73 \\
Humic-like 'A' & 6.45 & 2.05 & 46.81 \\
Fluorescence index & - & - & 1.68 \\
\hline
\end{tabular}

Proportion of fluorescence corresponding to fluorophore designations: $\mathrm{B}, \mathrm{T}, \mathrm{A}$, relative to the total fluorescence within a sample. Fluorescence was normalized to maximum and minimum fluorescence values across the three samples. The fluorescence index was calculated for samples meeting index criteria. The dashes indicate that the fluorescence index was not reported becouse the sample does not meet index criteria due to the lack of pesk fluorescence at $370 \mathrm{~nm}$ excitation and $470 \mathrm{~nm}$ ernission.

by radiolabelled isotopic incorporation assays ${ }^{17}$. Variations in extracellularly released carbon across aquatic systems $(<2 \%-70 \%$ (refs 16,18)) are governed by environmental factors such that temperature, nutrients and light availability have significant effects on the amount of carbon released and processed. To assess the importance of excreted OC to overall bacterial productivity in the stream, we determined the bacterial OC demand to be $0.62 \mu \mathrm{g} \mathrm{Cl}^{-1} \mathrm{~d}^{-1}$, while the supply of excreted carbon was $2.32 \mu \mathrm{g} \mathrm{Cl}^{-1} \mathrm{~d}^{-1}$. From this comparison, we concluded that the in situ bacterial carbon demand was not only met by the carbon excreted by in-stream microbial phototrophs, but also approximately four times in excess, corroborating previous work in other microbially dominated, limnetic Antarctic environments ${ }^{19}$. Thus, our findings support the idea that microbially produced OC could appreciably impact the microbial activity of downstream ecosystems, and is therefore an important constituent of glacial and global carbon cycling. While the actual value of excreted carbon may be modest in global terms, its overall impact will be amplified by its highly labile nature, particularly under a warming climate.

In addition to the exudation of microbially derived $\mathrm{OC}$, viralinduced lysis of bacterial cells and grazing can be a major source of OC (ref. 20). Low viral to bacteria ratios (VBRs) have been associated, in part, with autochthonous OC substrates, while allochthonous carbon is believed to foster high VBRs in glaciated ecosystems ${ }^{21}$. Additionally, VBRs less than the 10:1 model are generally more prevalent in waters where bacterial concentrations are low, as in glacial streams $\mathrm{s}^{22}$. Our study determined that viruslike particle (VLP) abundance in the CG stream ranged from $7.84 \times 10^{2}$ to $1.56 \times 10^{3} \mathrm{VLP} \mathrm{ml}^{-1}$, and the VBRs ranged from 0.12 to 0.44 . VBRs in the CG stream were considerably lower than average VBRs in both marine (range 10-40, and in places exceeding $100)$, and polar inland waters (range 1-57) ${ }^{21}$. In two Vestfold Hills Antarctic lakes the VBR in summer was $\sim 5$ and 8 , with viral cell lysis contributing $<20 \%$ to the $\mathrm{OC}_{\text {pool }}{ }^{23}$. Although our study did not determine virus-induced $\mathrm{OC}$ release, the low viral abundance and VBRs in the CG stream strongly suggest minor viral effects. Phototrophs were consistently present in the stream throughout the sampling season; however, no rotifers or protists were observed in the planktonic community (Supplementary Table 1). These findings support our hypothesis that OC was predominantly derived from exudation of photosynthetically synthesized OC.

The CG stream bacterial assemblage, as determined by catalysed reported deposition fluorescent in situ hybridization (CARD-FISH), consisted of $4.93 \times 10^{4}$ cells ml $^{-1}, 85 \%$ of which were comprised of the following lineages: Bacteroidetes (40\%), Betaproteobacteria (30\%), and Alphaproteobacteria (15\%). Within the class Betaproteobacteria, the genus Polaromonas accounted for $56 \%$. These dominant lineages within the CG stream are globally relevant across glaciated ecosystems ${ }^{24}$ and were therefore selected for subsequent analyses. Importantly, on the basis of the predicted metabolic profile of the CG stream community, the phylotypes present have the
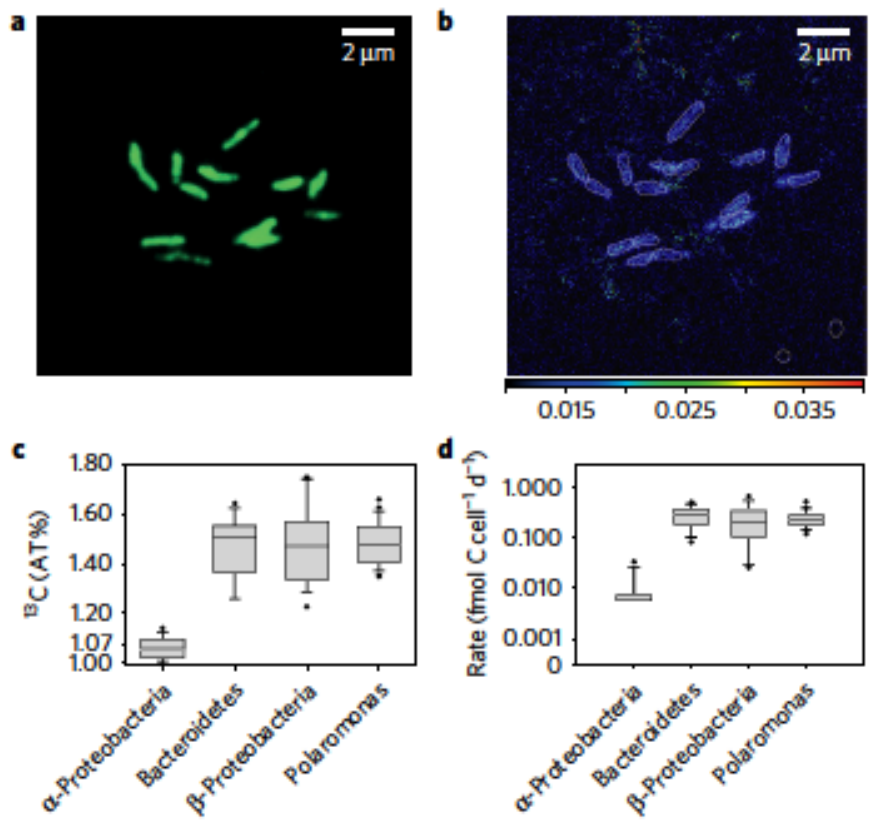

Flgure 1 | Microbial uptake of in situ released organic matter. a,b, Example of cells analysed. a, Epifluorescence overlay confirming identification of Polaromonas sp. cells hybridized with HRP-labelled Pomo828

oligonucleotide probe (green signal). b, NanoSIMS ${ }^{13} \mathrm{C} /{ }^{12} \mathrm{C}$ isotope ratio image of cells enriched in ${ }^{13} \mathrm{C}$-labelled exudates; white lines indicate regions of interest used for calculating ${ }^{13} \mathrm{C} /{ }^{12} \mathrm{C}$ ratios. $\mathbf{c}, \mathbf{d}$, Summary boxplots of nanoSIMS analyses in atom\% (AT\%) (c) and in fmol C cell ${ }^{-1} \mathrm{~d}^{-1}$ (d) for Alphaproteobacteria, Bacteroidetes, Betaproteobacteria and Polaromonas sp. Whiskers represent the 25 th and 75 th percentile (lower and upper quartiles, respectively); the mean is a solid line with outliers represented by a filled black circle.

metabolic capacity to degrade low-molecular-weight, carbohydratelike compounds (Supplementary Fig. 2).

\section{Microbially synthesized organic carbon is highly labile}

High-resolution nanometre-scale secondary ion mass spectrometry (nanoSIMS) was used to quantify the single-cell uptake of microbially synthesized and excreted ${ }^{13} \mathrm{C}$-labelled $\mathrm{OC}$, derived from an initial incubation of CG primary producers grown on $\mathrm{NaH}{ }^{13} \mathrm{CO}_{3}$ (Fig. la,b). ${ }^{13} \mathrm{C}$-labelled exudates were incorporated by Bacteroidetes and Betaproteobacteria, while no uptake was detected in Alphaproteobacteria ${ }^{13} \mathrm{C}$-enrichments (Fig. lc,d). In organisms where uptake was present, a linear mixed model was used to fit an analysis of variance with random effects; no statistically significant difference was found in uptake rates between the Bacteroidetes (range 0.0831-0.541 fmol C cell $\mathrm{fd}^{-1}$ ) and Betaproteobacteria (range 0.0256-0.669 fmol C cell ${ }^{-1} \mathrm{~d}^{-1}$ ) lineages $(P>0.05)$ (Supplementary Table 2 ). Photosynthetically derived exudates from the CG stream primary producers were capable of supporting bacterial growth demands, and were rapidly utilized ( $24 \mathrm{~h})$ by heterotrophic bacteria.

To confirm that there is discrimination in carbon preference between the dominant heterotrophs, rather than Alphaproteobacteria being senescent, a second set of incubations were amended with a commercial ${ }^{13} \mathrm{C}$-labelled algal amino acid mixture $\left({ }^{13} \mathrm{C}\right.$-AA; Cambridge Isotopes). All investigated phylogenetic lineages in the CG stream were enriched in ${ }^{13} \mathrm{C}$-AA (Supplementary Fig. 3 ) with incorporation rates ranging from $0.239-2.88 \mathrm{fmol} \mathrm{C}$ cell $^{-1} \mathrm{~d}^{-1}$ (Supplementary Table 2 ). The rate of ${ }^{13} \mathrm{C}$-AA assimilation was significantly lower for Bacteroidetes cells $(P<0.001)$ compared with the other lineages, while there was no significant difference in the rate between Alphaproteobacteria, Betaproteobacteria and Polaromonas sp. 


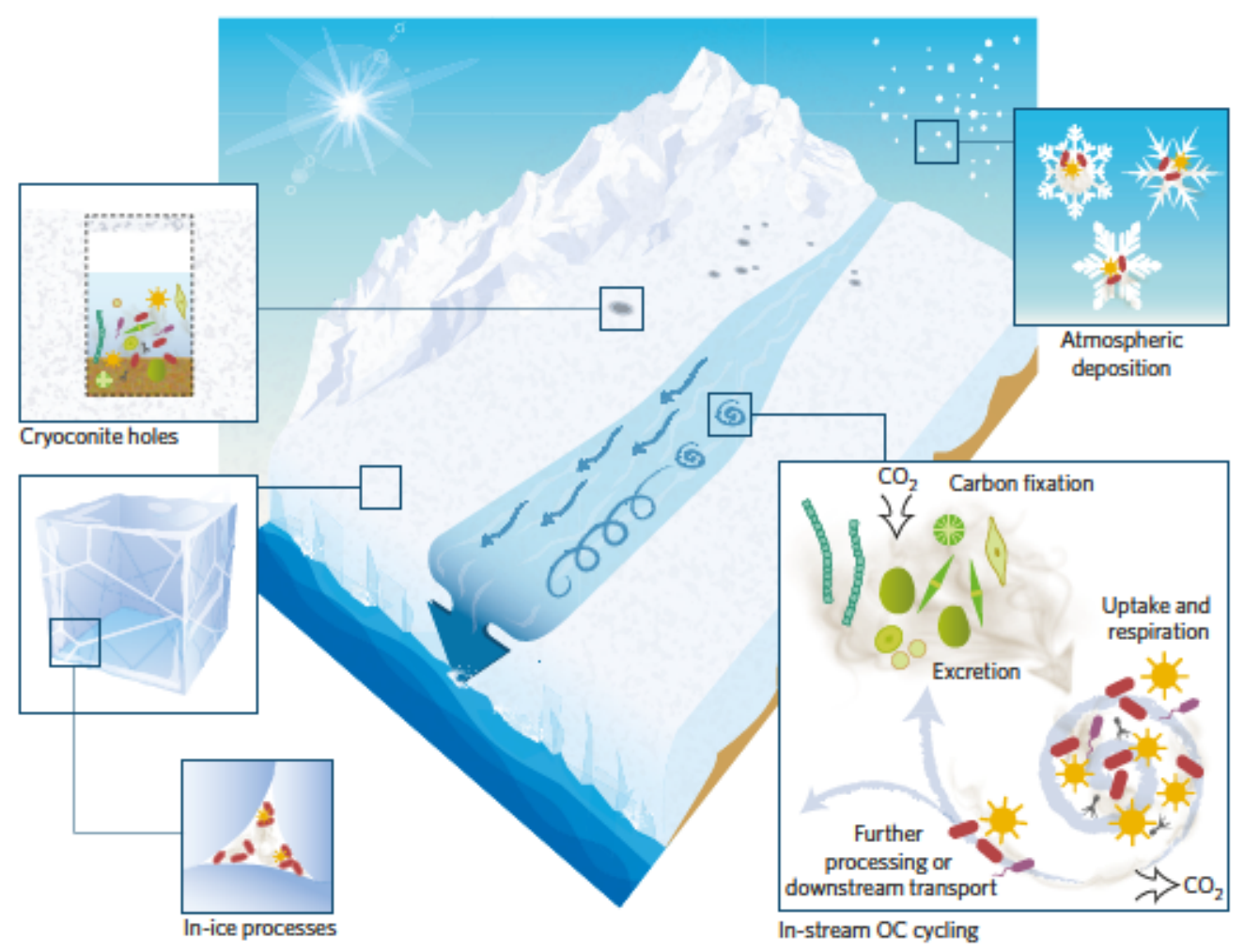

Flgure 2 | Organic carbon cycling in supraglacial environments. Schematic depicting sources and sinks of OC on glaciers. Four major compartments of supraglacial OC cycling are shown: cryoconites, aeolian deposition, in-ice processes and in-stream cycling. The first step in the supraglacial microbial loop (represented by spirals) is the fixation of atmospheric $\mathrm{CO}_{2}$ by photoautotrophic microorganisms; this fixed OC is released (brown cloud) and successively taken up by heterotrophic organisms. OC utilized by microorganisms is either partially or completely photo-oxidized or biologically oxidized to $\mathrm{CO}_{2}$. In-stream arrows represent OC being transported downstream with eventual export to the oceans.

$(P>0.093)$. An important consideration is that all measured uptake rates are underestimates, given the findings that ${ }^{13} \mathrm{C}$ (and ${ }^{15} \mathrm{~N}$ ) fractions are subject to dilution after treatment with chemical fixatives in the CARD-FISH assay ${ }^{25}$. Our ability to visualize and quantify the direct transfer of photosynthetically produced exudates to heterotrophic organisms reaffirms the critical role of microbially mediated carbon cycling on glacial surfaces.

\section{Release of microbially produced organic carbon}

These results provide new insight into carbon cycling in supraglacial aquatic systems; concurrent with this, remote sensing imagery has been used to document the extensive distribution of such systems in Antarctica, indicating that they may commonly occur in summer on the Antarctic ice sheet (AIS) ${ }^{26}$. Although glacial environments harbour relatively low amounts of OC, because of their sheer mass and surface area (approximately $11 \%$ of the Earth's surface is covered by ice) they represent an important component of the global carbon cycle ${ }^{1,827}$. Variability exists in estimates of the concentration of $\mathrm{OC}$ stored within ice masses, ranging between 0.11 and $0.40 \mathrm{mg} \mathrm{Cl}^{-1}$ for the AIS alone ${ }^{1.28}$. Thus, based on the number, type and location of samples included in these calculations, $~ 3.3-8.4 \mathrm{Gt}$ of $\mathrm{OC}$ could be contained within the AIS, with the upper range expanding on previous global estimates of six gigatons ${ }^{2729}$. Under a warming summer climate, more supraglacial systems may emerge, potentially increasing the contribution of autochthonously derived OC to the glacial OC pool.

To place the findings of this study within a broader context we calculated a conservative estimate of the amount of labile carbon, in excess of uptake, exported annually from the surface of Antarctica. This excess fraction of labile OC may enhance downstream microbial production, affecting ecosystem function and biogeochemical cycles (Fig. 2). Isotopic analysis was used to quantify the amount of exuded carbon from the CG stream. Combining the average excess of exuded OC $\left(2.17 \mu \mathrm{g} \mathrm{Cl}^{-1} \mathrm{~d}^{-1}\right)$, the number of days of stream flow representative of Antarctic streams (60 days ${ }^{28}$ ), and the discharge of the CG stream as calculated by acoustic Doppler velocimeter measurements $\left(0.119 \mathrm{~m}^{3} \mathrm{~s}^{-1}\right.$ (ref. 12)), we conservatively estimate that $8.03 \times 10^{4} \mathrm{~g} \mathrm{C}$ could be exported from the CG stream per year. A modest upper estimate of the flux of excess exuded carbon is based on continuous discharge measurements from the nearby Onyx River. The Onyx flows (http://www.mcmlter.org) during 2010/11 were tenfold higher than flows for the CG stream measured in $2009 / 10$. Therefore, during higher flow seasons $8.03 \times 10^{5} \mathrm{~g} \mathrm{C}$ could be potentially transported from the CG stream. Using a mean continent-wide meltwater volume, excluding floating ice shelves, of $32 \times 10^{12} \mathrm{lyr}^{-1}$ (ref. 30) multiplied by our estimate of summer exuded carbon, we estimate that $0.69 \mathrm{Gg} \mathrm{C}$ could be discharged yearly from the AIS surface. In the absence of direct runoff measurements, our estimation solely refers to excess biologically labile $\mathrm{OC}$, and therefore may underestimate total carbon transport from the AIS. This estimated OC flux is one to two orders of magnitude lower than estimates from the Greenland ice sheet ${ }^{4.31}$. However, we acknowledge that these extrapolations are oversimplifications with flux estimates inferred by assuming a consistent production of excess carbon throughout the stream for the duration of flow.

As estimates of glacial OC are refined with more data it is important to consider that $\mathrm{OC}$ is not uniform in nature across glacial environments. On the basis of the experimental design of previous bioavailability studies on bulk glacial OC, which masked the contribution of highly biolabile OC (uptake within hours), it was concluded that ancient carbon constitutes the labile fraction of glacial $\mathrm{OC}^{1,3}$. The present study provides the first direct evidence that $\mathrm{OC}$ produced by microbial phototrophs is a highly 
bioavailable substrate for supraglacial stream communities, supporting a dynamic carbon cycle. Our findings regarding the microbial production of $\mathrm{OC}$ add another source to the initial scenario that old carbon locked in ice is the primary contributor to glacial carbon cycling ${ }^{2}$. Further refinement of approaches are needed to quantify the uptake of both ancient and photosynthetically produced OC, which will build towards a more accurate determination of glacial carbon fluxes.

\section{Methods}

Methods, including statements of data availability and any associated accession codes and references, are available in the online version of this paper.

Received 28 June 2016; accepted 27 February 2017; published online 3 April 2017

\section{References}

1. Hood, E. et al. Glaciers as a source of ancient and labile organic matter to the marine environment. Nat. Geosci. 462, 1044-1047 (2009).

2. Stubbins, A. et al. Anthropogenic aerosols as a source of ancient dissolved organic matter in glaciers. Nat. Geosci. 5, 198-201 (2012).

3. Singer, G. A. et al. Biogeochemically diverse organic matter in Alpine glaciers and its downstream fate. Nat. Geosci. 5, 710-714 (2012).

4. Bhatia, M. P. et al. Organic carbon export from the Greenland ice sheet. Geochim. Cosmochim. Acta 109, 329-344 (2013).

5. Antony, R. et al. Origin and sources of dissolved organic matter in snow on the East Antarctic ice sheet. Environ. Sci. Technol, 48, 6151-6159 (2014).

6. Smith, H. J. et al. Biofilms on glacial surfaces: hotspots for biological activity. NPJ Biofilms Microbiomes 2, 16008 (2016).

7. Cook, J., Edwards, A., Takeuchi, N. \& Irvine-Fynn, T. Cryoconite: the dark biological secret of the cryosphere. Prog. Phys. Geogr. 40, 66-111 (2016).

8. Anesio, A. M., Hodson, A. J. \& Fritz, A. High microbial activity on glaciers: importance to the global carbon cycle. Glob. Change Biol. 15 955-960 (2009).

9. Li, F, Ginoux, P. \& Ramaswamy, V. Distribution, transport, and deposition of mineral dust in the Southern Ocean and Antarctica: contribution of major sources. J. Geophys. Res. 113 (2008).

10. Bauer, S. E. et al. Historical and future black carbon deposition on the three ice caps: ice core measurements and model simulations from 1850 to 2100 . J. Geophys. Res. 118, 7948-7961 (2013).

11. Stibal, M., Sabacka, M. \& Zarsky, J. Biological processes on glacier and ice sheet surfaces. Nat. Geosci. 5, 771-774 (2012).

12. Sanclements, M. D. et al. Biogeophysical properties of an expansive Antarctic supraglacial stream. Ant. Sci. 29, 33-44 (2017).

13. Foreman, C. M. et al. Microbial growth under humic-free conditions in a supraglacial stream system on the Cotton Glacier, Antarctica. Environ. Res. Lett. 8, 035022 (2013).

14. Barker, J. D., Dubnick, A., Lyons, W. B. \& Chin, Y. P. Changes in dissolved organic matter (DOM) fluorescence in proglacial Antarctic streams. Arct. Ant. Alp. Res. 45, 305-317 (2013).

15. Ogawa, H., Amagai, Y., Koike, I., Kaiser, K. \& Benner, R. Production of refractory dissolved organic matter by bacteria. Science 292, 917-920 (2001).

16. Teira, E., Pazó, M. J. \& Serret, P. Dissolved organic carbon production by microbial populations in the Atlantic Ocean. Limnol. Oceanogr. 46, 1370-1377 (2001).

17. Coveney, M. F. Bacterial uptake of photosynthetic carbon from freshwater phytoplankton. Oikos 38, 8-20 (1982).

18. Van den Meersche, K. \& Middelburg, J. J. Carbon-nitrogen coupling and algal-bacterial interactions during an experimental bloom: modeling a ${ }^{13} \mathrm{C}$ tracer experiment. Limnol. Oceanogr. 49, 862-878 (2004).
19. Takacs, C. D., Priscu, J. C. \& McKnight, D. M. Bacterial dissolved organic carbon demand in McMurdo Dry Valley lakes, Antarctica. Limnol. Oceanogr. 46, 1189-1194 (2001).

20. Suttle, C. A. Marine viruses-major players in the global ecosystem. Nat. Rev. Microbiol. 5, 801-812 (2007).

21. Sāwström, C., Lisle, J., Anesio, A. M., Priscu, J. C. \& Laybourn-Parry, J. Bacteriophage in polar inland waters. Extremophiles 12, 167-175 (2008).

22. Wigington, C. H. Re-examination of the relationship between marine virus and microbial cell abundances. Nature 1, 15024 (2016).

23. Sāwström, C., Anesio, M. A., Granéli, W. \& Laybourn-Parry, J. Seasonal viral loop dynamics in two large ultraoligotrophic Antarctic freshwater lakes. Microb. Ecol. 53, 1-11 (2007).

24. Boetius, A., Anesio, A. M., Deming, J. W., Mikucki, J. A. \& Rapp, J. Z. Microbial ecology of the cryosphere: sea ice and glacial habitats. Nat. Rev. Microbiol. (2015).

25. Musat, N. et al. The effect of FISH and CARD-FISH on the isotopic composition of ${ }^{13} \mathrm{C}$ - and ${ }^{15} \mathrm{~N}$-labeled Pseudomonas putida cells measured by nanoSIMS. Syst. Appl. Microbiol. 37, 267-276 (2014).

26. Langley, E. S., Leeson, A. A., Stokes, C. R. \& Jamieson, S. S. R. Seasonal evolution of supraglacial lakes on an East Antarctic outlet glacier. Sci. Invest. Rep. 43, 8563-8571 (2016).

27. Priscu, J. C. \& Christner, B. C. Microbial Diversity and Bioprospecting (ed. Bull, A.) (ASM Press, 2004)

28. Kohler, T. J. et al. Life in the main channel: long-term hydrologic control of microbial mat abundance in McMurdo Dry Valley streams, Antarctica. Ecosystems 18, 310-327 (2015).

29. Hood, E., Battin, T. J., Fellman, J., O'Neel, S. \& Spencer, R. G. M. Storage and release of organic carbon from glaciers and ice sheets. Nat. Geosci. 8, 91-96 (2015).

30. Kuipers Munneke, P., Picard, G., Broeke den, M. R., Lenaerts, J. T. M. \& Meijgaard, E. Insignificant change in Antarctic snowmelt volume since 1979. Sci. Invest. Rep. 39 (2012).

31. Hodson, A. et al. The cryoconite ecosystem on the Greenland ice sheet. Ann. Glaciol. 51, 123-129 (2010).

\section{Acknowledgements}

This work was supported by the National Sctence Foundation Diviston of Antarctic Sclences through ANT-0838970 and ANT-1141978 to C.M.E., by the NSF Division of Graduate Education through DGE-0654336, and through a NASA Earth and Sclence Space Fellowship to H.JS. The Max Plank Soctety (MPG) supported the nanoSIMS and EA-IRMS analyses. D. Thenken, G. Klockgether, L. Polerecky and G. Lavik from MPI Bremen are acknowledged for assistance in the nanoSIMS and EA-IRMS analyses. R.A.F is currently funded by the Knut and Alice Wallenberg Foundation and ${ }^{13} \mathrm{C}$-DOC measurements were supported by an NSF grant to R.A.F. (BIO-OCE0929015) as well as by the MPG. We thank A. Parker from the Center for Btofilm Engineering at Montane State University for statistical guidance. FlowCAM image analysts was conducted by I. P. Daring at INSTAAR, The Untversity of Colorado. Flow cytometry was performed by D. Dunigan and A. Esmael, Untversity of Nebraska-Lincoln. Any optnions, findings, or condusions expressed in this material are those of the authors and do not necessarily reflect the views of the National Sclence Foundation.

\section{Author contributions}

H.J.S., C.M.F and R.A.F. concetved and designed experiments. H.J.S., C.M.F., S.L. and J.T.L performed the experiments. H.JS., C.M.F., R.A.F., S.L., D.M.M. and J.T.L analysed the data. C.M.F., J.T.L. and M.M.M.K. contributed matertals/analysts tools. H.J.S., C.M.E., R.A.F. and D.M.M. wrote the paper.

\section{Additional information}

Supplementary information is avallable in the online version of the paper. Reprints and permissions information is avallable online at www.nature.com/reprints. Publisher's note: Springer Nature remains neutral with regard to furisdictional claims in published maps and institutional affiliations. Correspondence and requests for matertals should be addressed to C.M.F

\section{Competing financial interests}

The authors declare no competing financtal interests. 


\section{Methods}

Sample site description and bulk biological analyses. Samples were collected throughout two field seasons (November 2010-January 2011, and December 2011-January 2012) from the CG stream $\left(77^{\circ} 07^{\prime} \mathrm{S} 161^{\circ} 40^{\prime} \mathrm{E}\right)$. Background biogeochemical parameters were collected throughout both field seasons; however, data collected for nanoSIMS were collected only during the second season. The CG stream is a supraglacial stream consisting of a network of braided channels that flows over ice and mostly lacks a sediment/water interface. The CG stream is approximately $16 \mathrm{~km}$ long and ultimately terminates into the Ross Sea. Stream water was collected in milli-Q-rinsed fluorinated carboys, and transported to either the Lake Fryxell field camp or McMurdo Station within $2 \mathrm{~h}$ for subsequent analyser.

Bacterial productivity was measured with ${ }^{3} \mathrm{H}$-leucine incorporation (final concentration $20 \mathrm{nM}$ ) following the protocol described in ref. 32. Leucine incorporation assays were performed in triplicate with two corresponding formalin-killed controls ( $5 \%$ formalin added $30 \mathrm{~min}$ prior to ${ }^{3} \mathrm{H}$-leucine addition); samples were incubated at $4^{\circ} \mathrm{C}$ for $24 \mathrm{~h}$. Primary productivity (PPR) was measured

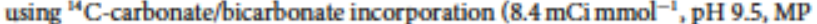
Biomedicals) following the protocol of ref. 33. Five light assays were run per sample in combination with three dark controls. All samples were incubated in a light incubator closely mimicking environmental conditions $\left(50.6\right.$ photons $\left.\mathrm{m}^{-1}\right)$ at $4{ }^{\circ} \mathrm{C}$ for $24 \mathrm{~h}$. After incubation, samples were gently filtered ( $<7 \mathrm{psi})$ through pre-combusted GF/F filters in the dark. Filters were then placed into $20 \mathrm{ml}$ scintillation vials, acidified with $500 \mu \mathrm{ll} 3 \mathrm{M} \mathrm{HCl}$ and allowed to dry at $60^{\circ} \mathrm{C}$ for $8 \mathrm{~h}$. Samples for extracellular release measurements were performed in triplicate with

${ }^{44} \mathrm{C}$-bicarbonate amendments ( $8.4 \mathrm{mCi} \mathrm{mmol}^{-1}, \mathrm{pH} 9.5$, MP Biomedicals), following a $24 \mathrm{~h}$ incubation under environmentally relevant conditions (same as above). The samples were gravity filtered to minimize any artificial enhancement of extracellularly released carbon due to autotrophic cellular damage. The filtrate was collected in clean borosilicate bottles, acidified to a $\sim \mathrm{pH} 2.0$ with $6 \mathrm{~N} \mathrm{HCl}$, sparged with $\mathrm{N}_{2}$ gas to remove any unincorporated dissolved inorganic carbon and dried on a warming plate at $60^{\circ} \mathrm{C}$. For both PPR and extracellular release (ECR) samples, $10 \mathrm{ml}$ of Ecolume scintillation cocktail was added to each scintillation vial and samples were analysed using a liquid scintillation counter (Beckman LS 6000). Percentage of extracellular release (PER) was calculated as follows:

$\mathrm{PER}=\mathrm{ECR} /$ total PPR $\times 100$ (ref. 17). Aliquots for ${ }^{13} \mathrm{C}$-DOC analysis were immediately frozen and stored $\left(-20^{\circ} \mathrm{C}\right)$ in acid-cleaned and combusted amber vials. ${ }^{13} \mathrm{C}-\mathrm{DOC}$ samples were analysed at the University of California, Davis stable isotope facility using an O.I. Analytical Model 1010 TOC analyser interfaced to a PDZ Europa 20-20 isotope ratio mass spectrometer (Sercon). Bacterial productivity, PPR and PER were measured six times throughout a sampling season.

Determination of the biological carbon demand followed the calculations described in ref. 34, where bacterial rates of heterotrophic bacterial productivity were converted to bacterial carbon production and considered the biological carbon demand (D). The supply of $\mathrm{OC}$ from excreted products was calculated as a percentage from the total PPR (S). Finally, comparison of the D/S ratios was used to determine that the bacterial carbon demand was met by the supply of exuded carbon. To calculate the amount of $\mathrm{OC}$ in excess of the bacterial carbon demand the average uptake of ${ }^{13} \mathrm{C}$-labelled exudates, as determined by nanoSIMS, was subtracted from the total amount of exuded carbon.

Stable isotope labelling and incubation experiments. Catalysed reporter deposition fluorescent in situ hybridization secondary ion mass spectrometry (CARD-SIMS) was used to determine the rate and identity of the organisms responsible for the uptake of exuded photosynthate products"s. Whole water samples from the CG stream were initially incubated with ${ }^{13} \mathrm{C}$-labelled bicarbonate ( $\sim 99 \%{ }^{13} \mathrm{C}$, Cambridge Isotopes Laboratories, $1 \mathrm{mM}$ final concentration, which did not change the overall $\mathrm{pH}$ ) in 11 bottles in a light incubator to simulate in situ light $\left(50.6\right.$ photons $\left.\mathrm{m}^{-2}\right)$ and temperature $\left(4^{\circ} \mathrm{C}\right)$ conditions for $72 \mathrm{~h}$. After the $72 \mathrm{~h}$ incubation cellular biomass and incorporated ${ }^{13} \mathrm{C}$-labelled bicarbonate were removed with filtration ( $<7 \mathrm{psi}$ ), while the filtrate containing the newly ${ }^{13} \mathrm{C}$-labelled exudates was collected. The filtrate was acidified to $\sim \mathrm{pH} 3.5$ and sparged with $\mathrm{N}_{2}$ gas for $1 \mathrm{~h}$ to remowe any unincorporated ${ }^{13} \mathrm{C}$-labelled bicarbonate. After sparging, the $\mathrm{pH}$ of the exudates was brought back to $\sim \mathrm{pH} 7.0$, which is the $\mathrm{pH}$ of the CG stream. Samples were collected for ${ }^{\mathrm{D}} \mathrm{C}$-DOC analysis (see above) to determine the starting concentration of exudates, which was necessary for uptake calculations.

CG stream water containing the active microbial assemblage was then added to the newly synthesized ${ }^{13} \mathrm{C}$-exudates and incubated under the same conditions as above for $24 \mathrm{~h}$. An additional aliquot of CG stream water was incubated with

${ }_{0.05}^{13}$-labefled algal amino acids ( $\sim 99 \%{ }^{13} \mathrm{C}$ Cambridge Isotopes Laporatories $\mathrm{C}$. After incubation, samples were amended with paraformaldehyde (final concentration $2 \%$ ) and incubated for $1.5 \mathrm{~h}$ at room temperature. Subsamples $(10 \mathrm{ml})$ were then filtered onto pre-sputtered gold/palladium $25 \mathrm{~mm}$ (diameter) $0.2 \mu \mathrm{m}$ pore size GTTP polycarbonate filters (Millipore) under low vacuum pressure ( $<7 \mathrm{psi}$ ) and washed three times with $1 \times$ phosphate-buffered saline (PBS). Filters were dried and stored in cryovials at $-20^{\circ} \mathrm{C}$ until further processing.

Hybridization and microscopic evaluation. Sections ( $5 \mathrm{~mm}$ diameter) of filters were excised and hybridized with horseradish peroxidase (HRP)-labelled oligonucleotide probes following the CARD-FISH protocol described by ref. 36. To avoid detachment of cells throughout sample preparation, filters were initially embedded in $0.1 \%$ low-melting-point agarose. Gram-negative bacterial cells were permeabilized with a lysozyme (10 $\mathrm{mg} \mathrm{m}^{-1}$ in $\left.0.05 \mathrm{M} \mathrm{EDTA}, \mathrm{pH} 8.0\right)$ and $0.1 \mathrm{M}$ Tris-HCl treatment at $37^{\circ} \mathrm{C}$ for $1 \mathrm{~h}$. After permeabilization filters were washed three times with ultrapure water (MQ, Millipore) and endogenous peroxidases were bleached with $3 \% \mathrm{H}_{2} \mathrm{O}_{2}$ at $20^{\circ} \mathrm{C}$ for $10 \mathrm{~min}$. Prior to hybridization, filters were washed three times for $1 \mathrm{~min}$ with ultrapure water, submerged in $96 \%$ ethanol for $1 \mathrm{~min}$, and allowed to air dry completely. Filters were subjected to a $1 \mathrm{~h}$ pre-hybridization step without the probe, then probes were added $(1: 150 \mathrm{v} / \mathrm{v})$ and hybridized at $46^{\circ} \mathrm{C}$ for $6 \mathrm{~h}$ using a previously described protocol ${ }^{\mathrm{I}}$. The oligonucleotide probes and corresponding formamide concentrations used for this study are provided in Supplementary Table 3. For FISH with horseradish peroxidase (HRP)-labelled oligonucleotide probes a tyramide signal amplification step was done following the protocol described in ref. 37, where hybridized cells were counterstained with $4^{\prime}, 6^{\prime}$-diamindino-2-phenylindole (DAPI) at a final concentration of $1 \mathrm{\mu g} \mathrm{ml}^{-1}$ in the dark for $10 \mathrm{~min}$. Filter sections were covered in mounting solution containing 4 parts Citifluor (Citifluor) and 1 part VectaShield (Vector Laboratories). Ten randomly chosen fields (grid size of $15,625 \mu \mathrm{m}^{2}$ ) corresponding to $1,000-1,200$ DAPI-stained cells were counted using a Zeiss Axioskop II fluorescence microscope (Zeiss) with a final magnification of $\times 1,000$. Counts are reported as mean averages from triplicate cell counts that have been converted on the basis of phylogenetic classification to percentages of the total number of cells counted. Areas of interest for nanoSIMS were marked with arrows and numbers using a Laser Micro Dissection microscope 6500 (Leica). Microscopic pictures were taken and used for orientation purposes during the subsequent nanoSIMS analysis and post-processing using look@nanoSIMS software (see below).

NanoSIMS analysis. NanoSIMS analysis was performed using a Cameca NanoSIMS 50L instrument (Cameca). After re-identifying the laser-marked areas of interest with the CCD (charge-coupled device) camera, samples were pre-sputtered for 1-2 min and rastered with 1 to $2 \mathrm{pA}$ caesium $\left(\mathrm{Cs}^{+}\right)$primary ion beam and a beam size $<100 \mathrm{~nm}$. Mass resolving power in the majority of the measurements was $>8,000$. The areas of interest were analysed with a raster size from $10 \times 10 \mu \mathrm{m}$ and $50 \times 50 \mu \mathrm{m}$ and image sizes of $256 \times 256$ and $512 \times 512$ pixels, respectively. The primary ion beam was used to raster the analysed area ( $256 \times 256$ pixels) over the chosen raster size with a dwelling time of 1 or $2 \mathrm{~ms}$ per pixel. Negative secondary ions $\left({ }^{12} \mathrm{C}_{8}{ }^{13} \mathrm{C}_{3}{ }^{13} \mathrm{~F}_{2}{ }^{12} \mathrm{C}^{14} \mathrm{~N},{ }^{12} \mathrm{C}^{15} \mathrm{~N}\right.$ and ${ }^{12} \mathrm{~S}$ ) were collected simultaneously with electron multiplier detectors within the nanoSIMS multi-collection system. All recorded plane images (40-50 planes) were corrected after acquisition for image drift from layer to layer. Following drift correction, layers were accumulated using the look@nanoSIMS software package ${ }^{3}$. Isotope ratio images were created as the ratio of a sum of counts for each pixel over all recoded planes of the investigated main isotope. Individual regions of interest were defined using the ${ }^{12} \mathrm{C}^{14} \mathrm{~N}\left({ }^{13} \mathrm{C}\right.$-labelled exudates) and ${ }^{12} \mathrm{~S}\left({ }^{13} \mathrm{C}\right.$-labelled algal amino acids) ratio images and were compared with fluorescent images for DAPI-stained and CARD-FISH hybridized cells.

The equations used for $\mathrm{C}$ assimilation were as previously described in ref. 39 and are summarized in Supplementary Table 5. All nanoSIMS enrichment and rate assimilation data were log transformed prior to statistical analysis with the stats package in $\mathrm{R}$ (ref. 40) where a liner mixed effects model was used to analyse ${ }^{13} \mathrm{C}$ enrichment for both of the tracers used in this study $\left({ }^{13} \mathrm{C}\right.$-labelled exudate, and ${ }^{13}$ C-labelled AA).

The ${ }^{13} \mathrm{C}$-initial of the cells was determined by elemental analysis-isotope ratio mass spectrometry (EA-IRMS), with these measurements used as the natural isotopic abundance values for ${ }^{\text {II }} \mathrm{C}$-initial. Briefly, whole water samples at time zero were filtered onto pre-combusted 25-mm-diameter Glass Fiber Filters (GFF; GE Healthcare Life Sciences) by gentle vacuum and stored frozen $\left(-20^{\circ} \mathrm{C}\right)$ until processed. The GFFs were dried overnight at $60^{\circ} \mathrm{C}$ in an oven, then acid fumed overnight in a desiccator with an open beaker of $37 \%$ hydrochloric acid (HCl) to remove inorganic $\mathrm{C}$ from the filters, and placed again at $60^{\circ} \mathrm{C}$ for $1 \mathrm{~h}$ to complete dehydration. The dried filters were weighed and packed for combustion analysis. The ${ }^{13} \mathrm{C}$ (AT\%) and the mass of particulate organic carbon (C) were analysed by an automated elemental analyser ('Thermo Flash EA, 1112 Series) coupled to a Delta Plus Advantage isotope ratio mass spectrometer ('Thermo Finnigan; EA-IRMS9). Instrument accuracy and precision were estimated at $1.065 \pm 0.002{ }^{13} \mathrm{C}$ AT\% based on the mean and standard deviation of caffeine standards measured in conjunction with the samples.

The natural abundance values were incorporated in the calculation to determine the labelling percentage and used to normalize the at\% enrichment of 
${ }^{13} \mathrm{C}$. All nanoSIMS enrichment and rate assimilation data were log transformed prior to statistical analysis with the stats package in $\mathrm{R}$ (ref. 40) where a liner mixed effects model was used to analyse ${ }^{13} \mathrm{C}$ enrichment for both of the tracers used in this study ( ${ }^{13} \mathrm{C}$-labelled exudate, and ${ }^{13} \mathrm{C}$-labelled algal amino acids).

Optical analysis. Organic material from the CG stream and subsequent experimental incubations were analysed using excitation emission matrices, which were collected over an excitation range of $240-450 \mathrm{~nm}$ in $10 \mathrm{~nm}$ increments while emission was monitored from 300 to $560 \mathrm{~nm}$ in $2 \mathrm{~nm}$ increments on a Fluoromax-4 spectrofluorometer (HORIBA Jobin-Ywon). Samples were analysed for UV absorbance with a Thermo Scientific Genesys 10 scanning UV spectrophotometer; from 190 to $1,100 \mathrm{~nm}$ on optically dilutes samples (absorbance values $<0.3$ at $254 \mathrm{~nm}$ ). Excitation emission matrix data were post-processed to correct for instrument-specific bias using manufacturer-generated correction files for excitation, emission, and blank subtraction. Fluorescence intensities were normalized across the three different samples (where $F_{\min } /\left(F_{\operatorname{mix}}-F_{\operatorname{man}}\right)$ ) and then specific regions of fluorescence were defined for each carbon source corresponding to previously identified natural organic matter fluorophores ${ }^{41}$. Fluorescence intensity values in the proteinaceous regions ( $\mathrm{B}$ and $\mathrm{T}$ fluorophores) were summed and classified as more-labile, while humic-like fluorescence intensities (A fluorophore) were combined and classified as less-labile and more recalcitrant. The fluorescence for defined regions was individually summed for each respective sample and presented as a percentage of the total fluorescence found in each sample. The fluorescence index (which characterizes the slope of the emission curve at an excitation of $370 \mathrm{~nm}$ ) was calculated for samples that met index criteria (fluorescence at $370 \mathrm{~nm}$ excitation and $470 \mathrm{~nm}$ emission) ${ }^{12}$. This index provides information about the source or degree of degradation.

Viral abundances. Water samples collected for bacterial and bacteriophage enumeration were collected in sterile flasks, immediately flash frozen in liquid nitrogen and kept at $-80^{\circ} \mathrm{C}$ until analysed. Samples were stained using SYBR Green I (Thermo Fisher Scientific) and counted using a Becton Dickinson FACSCalibur flow cytometer (BD Bioscience) ${ }^{43}$. Bacterial and viral counts were derived from the number of events retained within pre-determined regions for bacteria and viruses after approximately $10 \mathrm{~min}$ sampling intervals. The constraints for the bacteria and virus regions were based on distributions of known suspensions of SYBR Green I-stained bacteria and viruses.

Autotrophic community analysis. Samples were prepared for FlowCAM analysis following protocols of the Niwot-LTER (http://huey.colorado.edu/diatoms). Three $150 \mathrm{ml}$ aliquots of sample were reduced to a volume of $30 \mathrm{ml}$ by settling overnight and aspirating the overlying water. A $5 \mathrm{ml}$ volume of the concentrate was processed through the FlowCAM (Fluid Imaging Technologies) and $1 \mathrm{ml}$ was imaged. Many inorganic particles were detected in all the samples. The cyanobacteria and diatoms present were similar to those found in lakes and streams in the McMurdo Dry Valleys. The resolution of the FlowCAM allows probable identification to the family or genus level for cyanobacteria and to the genus level for the pennate diatoms based on the descriptions in the Antarctic Freshwater Diatoms database (http://huey.colorado.edu/diatoms). Image files of similarly settled samples from an alpine lake containing small coccoid cyanobacteria typically include numerous images of clumps of these cells; such clumps were not observed in the Cotton Glacier samples.

Data availability. The data that support the findings of this study are available from the corresponding author on request.

\section{References}

32. Kirchman, D., K'nees, E. \& Hodson, R. Leucine incorporation and its potential as a measure of protein synthesis by bacteria in natural aquatic systems. Appl Environ. Microbiol. 49, 599-607 (1985).

33. Lizotte, M. P., Sharp, T. R. \& Priscu, J. C. Phytoplankton dynamics in the stratified water column of Lake Bonney, Antarctica. Polar Biol. 16, 155-162 (1996).

34. Vick, T. J. \& Priscu, J. C. Bacterioplankton productivity in lakes of the Taylor Valley, Antarctica, during the polar night transition. Aquat. Microb. Ecol. 68, 77-90 (2012).

35. Musat, N. et al. A single-cell view on the ecophysiology of anaerobic phototrophic bacteria. Proc. Natl Acad. Sci. USA 105, 17861-17866 (2008).

36. Pernthaler, A. et al. Sensitive multi-color fluorescence in situ hybridization for the identification of environmental microorganisms. Mol. Microb. Ecol. Mamual 2, 711-725 (2004).

37. Pernthaler, A., Pernthaler, J. \& Amann, R. Fluorescence in situ hybridization and catalyzed reporter deposition for the identification of marine bacteria. Appl Environ. Microbiol. 68, 3094-3101 (2002).

38. Polerecky, L. Look@NanoSIMS-a tool for the analysis of nanosIMS data in environmental microbiology. Environ. Microbiol. 14, 1009-1023 (2012).

39. Foster, R. A. et al. Nitrogen fixation and transfer in open ocean diatom-cyanobacterial symbioses. ISME J. 5, 1484-1493 (2011).

40. R Development Core Team $R: A$ Language and Environment for Statistical Computing (R Foundation for Statistical Computing, 2008); http: $J /$ www.R-projectorg

41. Coble, P. G. Characterization of marine and terrestrial DOM in seawater using excitation-emission matrix spectroscopy. 51, 325-346 (1996).

42. McKnight, D. M., Boyer, E. W. \& Westerhoff, P. K. Spectrofluorometric characterization of dissolved organic matter for indication of precursor organic material and aromaticity. Limnol. Oceanogr. 46, 38-48 (2001).

43. Brussaard, C. P. D. Optimization of procedures for counting viruses by flow cytometry. Appl. Environ. Microbiol. 70, 1506-1513 (2004). 